\title{
Hasta Bakıcılarda Bel Ağrısı Ve Yaşam Kalitesinin Değerlendirilmesi, Turgut Özal Tıp Merkezi Örneği
}

\section{Lumbar Pain and Evaluated Life Quality in Patient Caregivers, Sample of Turgut Özal Medicine Center}

\author{
Betül Fırınci', Erkan Pehlivan², Gözde Nur Durmuş', Ali Özer² \\ 1 İnönü Üniversitesi Tıp Fakültesi, Halk Sağlığı AD, Malatya \\ 2 İnönü Üniversitesi Tıp Fakültesi, Halk Sağlığı AD, Malatya
}

Yazışma Adresi / Correspondence:

Betül Fırıncı

İnönü Üniversitesi Tıp Fakültesi Halk Sağlığı AD, Malatya

$\mathrm{T}:+905078152594 \quad$ E-mail: betul.firinci@inonu.edu.tr

Geliş Tarihi / Received : 02.04.2018 Kabul Tarihi / Accepted : 22.05.2018

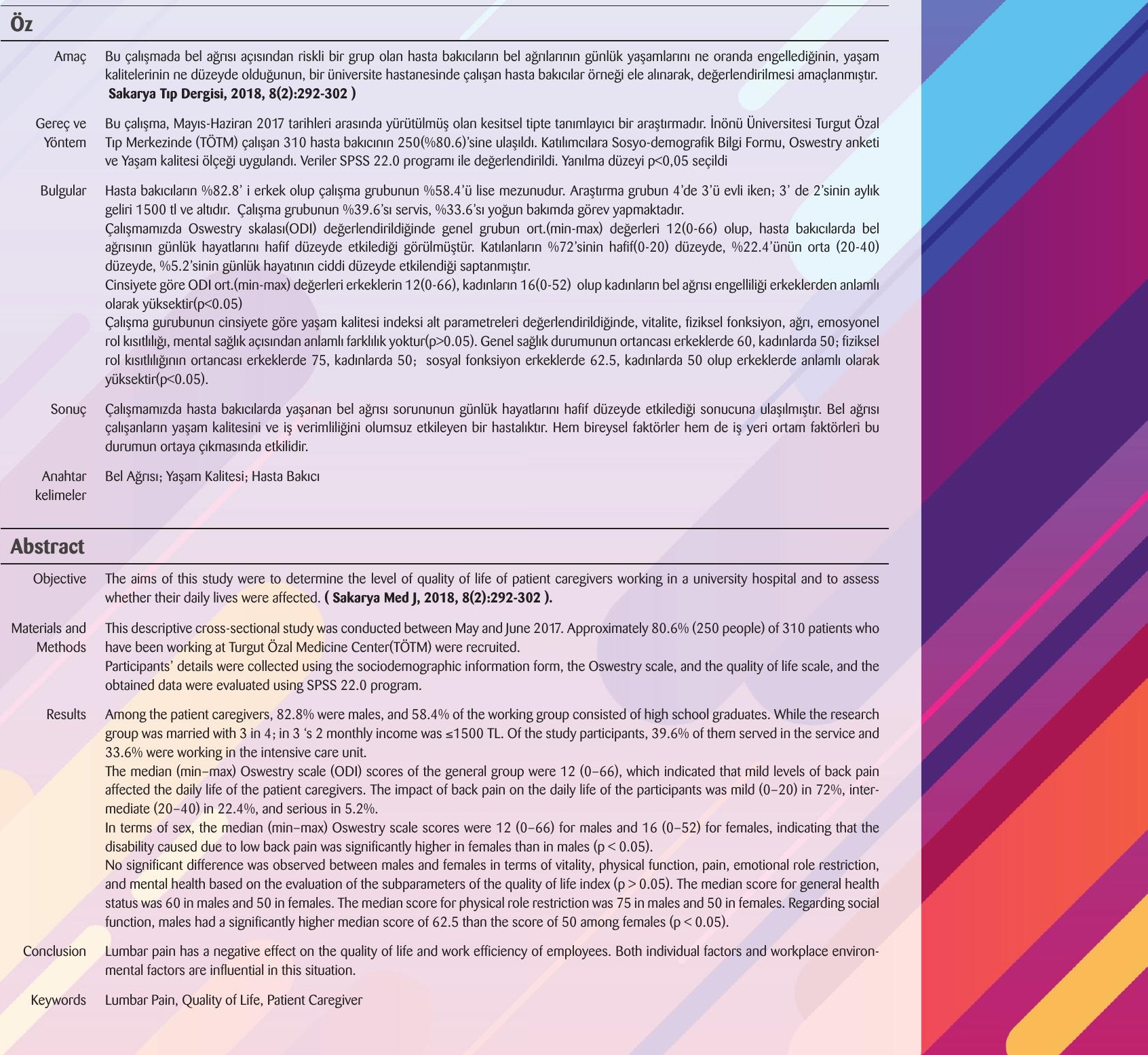


Sakarya TIp Dergisi 2018;8(2):292-302

\section{Giriş}

Bel ağrısı tüm ülkelerde toplumların genelini ilgilendiren, toplumlarda iş görmezliğe ve sağlık hizmetlerinin sık olarak kullanılmasına neden olan önemli bir halk sağlığı sorunudur. Her birey mutlaka hayatının bir döneminde bel ağrısı ile karşı karşıya kalmaktadır ve bu sorun çoğu zaman tekrar etmektedir. ${ }^{1}$ Kas iskelet sistemi hastalıkları için çeşitli bireysel, fiziksel, mesleksel, psikososyal risk faktörlerini tanımlamıştır. Kısıtlı duruşlar, güç gerektiren hareketler, çok sayıda ve /veya kritik hasta ile ilgilenme, yüksek duygusal gerginlik gibi durumlar bunlardan bazılarıdır. ${ }^{2}$ Sonuçta bel ağrısı yaygınlı̆̆ı, neden olduğu iş günü kayıpları, uzun süren tedavisi nedeniyle oluşan sağlık maliyeti açısından toplumların yaşam kalitesi ve ülkelerin ekonomisi üzerinde ciddi olumsuz etkileri olan bir sağlık sorunudur. ${ }^{1}$

Dünya Sağlık Örgütü yaşam kalitesini, "bireyin, gerek kültürel ve içinde bulunduğu ortamın değer yargıları, gerekse kendi hedefleri, beklentileri, standartları ve ilgileri bağlamında, hayatta kendi durumunu algılama biçimi” olarak tanımlamıştır. ${ }^{3}$ Bel ağrısının uzun süre devam etmesi hastaların yaşam kalitesinde bozulmalara neden olmakta, hastalarda üzüntü, çaresizlik duygularını ortaya çıkarmaktadır. Bazı hastalarda bel ağrısı depresyon ya da anksiyete bozukluğuna yol açabilmektedir. ${ }^{4}$ Bel ağrısı bireylerin yaşam kalitelerini belirgin derecede düşürebilmekte ve işi bırakma sebepleri içinde ikinci sırada gelmektedir. ${ }^{5}$ Bel ağrısı sık görülmesi, iş günü kayıplarına sebep olması, tedavisinin uzun sürmesi nedeniyle oluşan sağlık maliyeti dikkate alındığında hem toplumların yaşam kalitesi hem de ülkelerin ekonomileri üzerine ciddi olumsuz etkileri olan bir sağlık sorunudur. 2,6,7,8 Bu çalışmanın amacı bel ağrısı açısından riskli bir grup olan hasta bakıcılarda bel ağrılarının günlük yaşamlarını ne oranda engellediğini, yaşam kalitelerinin ne düzeyde olduğunu saptamaktır.

\section{Gereç ve Yöntem}

Bu çalışma, kesitsel tipte tanımlayıcı bir araştırma olup, Mayıs-Haziran 2017 tarihleri arasında İnönü Üniversitesi Turgut Özal Tıp Merkezinde (TÖTM) çalışan hasta bakıcılarda yapıldı. Çalışmanın yapılabilmesi için İnönü Üniversitesi Bilimsel Araştırma ve Yayın Etiği Kurulu ve Turgut Özal Tıp Merkezi Başhekimliğinden izin alındı. Çalışmanın yapıldığı dönemde Turgut Özal Tıp Merkezinde bulunan 310 hasta bakıcının tümünün araştırma kapsamına alınması planlandı. Örneklem seçimi yapılmadı. Hasta bakıcıların \%80,6'sına (250 kişi) ulaşıldı.

Sosyo-demografik Bilgi Formu, Oswestry anketi ve Yaşam kalitesi ölçeği katılımcılara gözlem altında uygulandı. Dünya Sağlık Örgütü(DSÖ)'nün sınıflamasına göre vücut kütle indeksi(VKi) (kg/m2) 18,5-24,99 arasındaysa normal, 25-29.99 arasındaysa fazla kilolu, $\geq 30$ ise obez olarak değerlendirilmiştir. Düzenli egzersiz haftada en az 3 gün, en az 30 dk süren egzersizi kapsamaktadır.

\section{Oswestry Anketi}

Türkçe geçerlik ve güvenilirliği Yakut ve arkadaşları tarafından yapılmış olan bu anket katılımcıların bel(veya bacak) yakınmasının günlük hayatlarını ne kadar etkilediği hakkında bilgi edinmek için kullanıldı. Ağrının yoğunluğu, kişisel bakım, yük kaldırma, yürüme, oturma, ayakta durma, uyku, cinsel hayat, sosyal hayat, seyahatin sorgulandığı, 10 alt gruptan oluşmaktadır ve her grup 6'lı likert tipinde olup 0-5 arasında puanlanmaktadır. Anketten alınabilecek toplam puan 0-50 arasında değişmektedir. Hastanın aldığı puan arttıkça günlük hayatın etkilenme oranı artmaktadır. 


\section{Yaşam Kalitesi Ölçeği}

Ware ve Sherbourne tarafından geliştirilen Koçyiğit ve arkadaşları tarafından Türkçeye çevrilip geçerlilik güvenirlik çalışması yapılan ölçek 36 sorudan oluşmaktadır. Bu ölçek; canlıık, fiziksel fonksiyon, ağ`ı, genel sağık durumu, fiziksel fonksiyon güçlüğü, emosyonel fonksiyon güçlüğü, sosyal fonksiyon, ruhsal sağlık alanlarını değerlendirmektedir. ${ }^{10}$

\section{İstatistiksel Yöntem}

Veriler SPSS 22.0 programı ile değerlendirildi. Örneklem büyüklüğü dikkate alınarak yapılan Shapiro-Wilk testinde yaşam kalitesi alt parametrelerden canlılık parametresinin normal dağlıma uyduğu ( $p>0.05$ ), diğer parametrelerin ise normal dağılıma uygun olmadığı görüldü $(p<0.05)$. i̇statistiksel analizlerde İndependent Sample t Test, One-Way ANOVA, Mann Whitney U, Kruskal Wallis, post hoc test olarak Bonferroni analizi kullanıldı. Elde edilen veriler, yüzdelik, ortanca, minimum ve maksimum, aritmetik ortalama, standart sapma kullanılarak değerlendirildi. Tüm analizlerde $p<0.05$ değerleri anlamlı kabul edildi.

\section{Bulgular}

Çalışma grubunun yaş ortalaması 37.3'dür. Çalışmaya katılan hasta bakıcıların \%82.8' i erkek, \%17.2'si kadındır. Çalışma grubunun \%58.4'ü lise mezunu, \%18.4'ü ise üniversite mezunudur. Araştırma grubunun 4'de 3'ü evli iken; 3' de 2'sinin aylık geliri 1500 tl ve altıdır. Çalışma grubunun \%39.6'sı servis, \%33.6'sı yoğun bakımda görev yapmaktadır. Sürekli gündüz çalışanlar çalışma grubunun \%56.4'ünü oluşturmaktadır. Çalışma yılı 0-5 yıl olanlar katılımcıların \%30.4'ünü, 6-10 yıl olanlar ise \%28.4'ünü oluşturmaktadır. Araştırma grubunun \%40.8'inin VKi normal sınırlarda, $\% 42.8^{\prime}$ i fazla kilolu, $\% 12.8$ 'i ise obezdir. Çalışma grubunun yarısı sigara kullandığını ifade etmiştir. Grubun \%72.4'ünün ailesinde kendisinden başka çalışan yoktur (Tablo 1).

\begin{tabular}{|l|l|l|}
\hline Tablo1. Katılımcıların Sosyo-demografik Özellikleri & $\%$ \\
\hline Özellikler & N & \\
\hline Cinsiyet & & 82.8 \\
\hline Erkek & 207 & 17.2 \\
\hline Kadın & 43 & \\
\hline Yaş & & 18.4 \\
\hline $0-30$ & 46 & 23.2 \\
\hline $31-35$ & 58 & 24 \\
\hline $36-40$ & 60 & 20 \\
\hline $41-45$ & 50 & 14.4 \\
\hline$>45$ & 36 & \\
\hline Eğitim Durumu & & 23.2 \\
\hline İlköğretim ve altı & 58 & 58.4 \\
\hline Lise & 146 & 18.4 \\
\hline Üniversite & 46 & \\
\hline Medeni Durum & & 76.8 \\
\hline Evli & 192 & 18.8 \\
\hline Bekar & 47 & 4.4 \\
\hline Eşi vefat etmiş/Boşanmış & 11 & \\
\hline & & \\
\hline
\end{tabular}

\section{Sakarya Tip Dergisi} 2018;8(2):292-302

FIRINCI ve Ark. Hasta Bakııllarda Bel Ağrnsı Ve Yaşam Kalitesinin Değerlendirilmesi, Turgut Özal Tip Merkezi Örneği 


\begin{tabular}{|c|c|c|}
\hline \multicolumn{3}{|l|}{ Çocuk sayısı } \\
\hline 0 & 64 & 25.6 \\
\hline 1 & 40 & 16 \\
\hline 2 & 76 & 30.4 \\
\hline 3 & 49 & 19.6 \\
\hline 4 ve üzeri & 21 & 8.4 \\
\hline \multicolumn{3}{|c|}{ Ailenin Toplam Aylık Geliri } \\
\hline $0-1500 \mathrm{tl}$ & 171 & 68.4 \\
\hline $1501-3000 \mathrm{tl}$ & 63 & 25.2 \\
\hline 3001 ve üzeri & 16 & 6.4 \\
\hline \multicolumn{3}{|c|}{ Ailede Başka Çalışan Varlığı } \\
\hline Evet & 69 & 27.6 \\
\hline Hayıг & 181 & 72.4 \\
\hline \multicolumn{3}{|l|}{ Çalışma yılı } \\
\hline $0-5$ & 76 & 30.4 \\
\hline $5.1-10$ & 71 & 28.4 \\
\hline 10.1-15 & 45 & 18 \\
\hline$>15.1$ & 58 & 23.2 \\
\hline \multicolumn{3}{|l|}{ Çalışma şekli } \\
\hline Sürekli Gündüz & 141 & 56.4 \\
\hline Sürekli Gece & 63 & 25.2 \\
\hline Vardiya & 46 & 18.4 \\
\hline \multicolumn{3}{|l|}{ Çalışılan bölüm } \\
\hline Servis & 99 & 39.6 \\
\hline Yoğun Bakım & 84 & 33.6 \\
\hline Ameliyathane & 23 & 9.2 \\
\hline Acil Servis & 17 & 6.8 \\
\hline Diğer & 27 & 10.8 \\
\hline TOPLAM & 250 & 100 \\
\hline
\end{tabular}

Çalışmamızda Oswestry skalası (ODI) değerlendirildiğinde genel grubun ort.(min-max) değerleri 12(0-66) olup, hasta bakıcılarda bel ağrısının günlük hayatlarını hafif düzeyde etkilediği görülmüştür. Katılanların \%72'sinin hafif( $\% 0-\% 20)$ düzeyde, $\% 22,4$ 'ünün orta (\%20-040) düzeyde, $\% 5,2$ ’sinin günlük hayatının ciddi düzeyde( $\% 40-\% 60)$ etkilendiği saptanmıştır.

Cinsiyete göre ODI ort.(min-max) değerleri erkeklerin 12(0-66), kadınların 16(0-52) olup kadınların bel ağrısı engelliliği erkeklerden anlamlı olarak yüksektir $(p<0.05)$. Hasta bakıcıların sosyodemografik özelliklerine göre ODI değerlendirilmiştir. Bel ağrısı puan ort.(min-max) 31 - 35 yaşta 16(0-66) ilköğretim ve altı eğitimi olanlarda 13(0-66), gelir durumu 3001 tl ve üzeri olanlarda 20(0-52), hiç spor yapmayanlarda 14(0-58), tek çocuk sahibi olanlarda 15(0-52), 11-15 yıl çaIışanlarda 16(0-52) olarak bulunmuştur. Yaş grubu, VKi, eğitim durumu, medeni durum, çocuk sayısı, çalışma yılı, çalışa şekli, çalş̧ılan bölüm, sigara içme, spor yapma, ailenin toplam aylık geliri ve ailede başka çalışan varlığına göre ODI açısından gruplar arasında anlamlı fark yoktur ( $p$ $>0.05$ ) (Tablo 2). 


\begin{tabular}{|c|c|c|}
\hline Özellikler & $\mathrm{N}$ & $\%$ \\
\hline \multicolumn{3}{|l|}{ Cinsiyet } \\
\hline Erkek & $12(0-66)$ & 0.013 \\
\hline Kadın & $16(0-52)$ & \\
\hline \multicolumn{3}{|l|}{ Yaş } \\
\hline 30 ve altı & $9(0-58)$ & 0.634 \\
\hline $31-35$ & $16(0-66)$ & \\
\hline $36-40$ & $12(0-54)$ & \\
\hline $41-45$ & $12(0-52)$ & \\
\hline 46 ve üzeri & $12(0-58)$ & \\
\hline \multicolumn{3}{|l|}{ Eğitim Durumu } \\
\hline illköğretim ve altı & $13(0-66)$ & 0.977 \\
\hline Lise & $12(0-58)$ & \\
\hline Üniversite & $12(0-46)$ & \\
\hline \multicolumn{3}{|l|}{ Gelir Durumu } \\
\hline $1500 \mathrm{tl}$ ve altı & $12(0-58)$ & 0.293 \\
\hline $1501-3000 \mathrm{tl}$ & $12(0-66)$ & \\
\hline$>3001 \mathrm{tl}$ & $20(0-52)$ & \\
\hline \multicolumn{3}{|l|}{ Çalışılan Bölüm } \\
\hline Servis & $12(0-58)$ & 0.297 \\
\hline Yoğun Bakım & $12(0-54)$ & \\
\hline Ameliyathane & $10(0-48)$ & \\
\hline Acil & $10(0-34)$ & \\
\hline Diğer & $12(0-66)$ & \\
\hline \multicolumn{3}{|l|}{ Medeni durum } \\
\hline Evli & $12(0-58)$ & 0.615 \\
\hline Bekar & $12(0-66)$ & \\
\hline Eşi vefat etmiş/ Boşanmış & $12(0-52)$ & \\
\hline \multicolumn{3}{|l|}{ Çocuk sayısı } \\
\hline 0 & $10(0-66)$ & 0.746 \\
\hline 1 & $15(0-52)$ & \\
\hline 2 & $14(0-52)$ & \\
\hline 3 & $12(0-42)$ & \\
\hline 4 ve üzeri & $12(0-54)$ & \\
\hline \multicolumn{3}{|l|}{ Çalışma yılı } \\
\hline $0-5$ & $11(0-66)$ & 0.612 \\
\hline $6-10$ & $14(0-48)$ & \\
\hline $11-15$ & $16(0-52)$ & \\
\hline 16 ve üzeri & $12(0-58)$ & \\
\hline \multicolumn{3}{|l|}{ Spor } \\
\hline Hiç & $14(0-58)$ & 0.174 \\
\hline Ara sıra & $10(0-66)$ & \\
\hline Düzenli- aktif sporcu & $12(0-32)$ & \\
\hline \multicolumn{3}{|l|}{ BMI } \\
\hline $0-18.50$ & $14(0-38)$ & 0.924 \\
\hline
\end{tabular}

Sakarya Tip Dergisi

2018;8(2):292-302

FIRINCI ve Ark.

Hasta Bakııllarda Bel Ağrısı Ve Yaşam Kalitesinin

Değerlendirilmesi, Turgut Özal Tip Merkezi Örneği 


\begin{tabular}{|l|l|l|}
\hline $18.51-24.99$ & $12(0-58)$ & \\
\hline $25.0-29.99$ & $12(0-58)$ & \\
\hline 30 ve üzeri & $10(0-66)$ & \\
\hline Ailede başka çalışan varlığı & & \\
\hline Yok & $12(0-66)$ & 0.820 \\
\hline Eş & $16(0-52)$ & \\
\hline Anne-baba & $14(0-32)$ & \\
\hline Kardeş & $11(0-58)$ & \\
\hline Çocuk & $10(0-38)$ & \\
\hline Çalışma şekli & & \\
\hline Sürekli gündüz & $12(0-66)$ & 0.293 \\
\hline Sürekli gece & $10(0-52)$ & \\
\hline Vardiya & $13(0-54)$ & \\
\hline
\end{tabular}

Grubun yaşam kalitesi alt parametreleri değerlendirildiğinde, canlılık(AO $\pm S S) 54.7 \pm 21.7$, fiziksel fonksiyon (ort.(min-max)) 70(0-100), ağrı(ort.(min-max)) 67.5(10-100), mental sağlık (ort(min-max)) 72(12-100) genel sağlık (ort.(min-max)) 55(5-100) fiziksel rol kısıtlllı̆ıı(ort.(minmax)) 75(0-100) emosyonel rol kısıtllilğı (ort.(min-max)) 100(0-100) sosyal fonksiyon (ort.(minmax))62.5(0-100) olarak saptanmıştır.

Yaşam kalitesi indeksi alt parametreleri cinsiyete göre değerlendirildiğinde, canlılık, fiziksel fonksiyon, ağrı, emosyonel rol kıııtlıı̆̆ı, mental sağlık açısından anlamlı farklılık yoktur ( $p>0.05$ ) Genel sağlık durumunun ortancası erkeklerde 60 , kadınlarda 50; fiziksel rol kısıtlılı̆ı̆ın ortancası erkeklerde 75, kadınlarda 50; sosyal fonksiyonun ortancası erkeklerde 62.5, kadınlarda 50 olup gruplar arasındaki fark anlamlıdır( $p<0.05$ ) (Tablo 3) Kadın çalışanlarda yaşam kalitesi alt parametreleri erkek çalışanlara göre anlamlı olarak daha düşük bulunmuştur.

\begin{tabular}{|c|c|c|c|}
\hline & \multicolumn{2}{|l|}{ Cinsiyet } & \multirow[b]{2}{*}{$\rho$} \\
\hline & $\begin{array}{c}\text { Erkek } \\
\text { Ort.(Min-Max) }\end{array}$ & $\begin{array}{c}\text { Kadın } \\
\text { Ort.(Min-Max) }\end{array}$ & \\
\hline \multicolumn{4}{|l|}{ Yaşam Kalitesi } \\
\hline Vitalite (AO $\pm \mathrm{SS})$ & $55.79 \pm 21.05$ & $49.41 \pm 21.69$ & 0.073 \\
\hline Fiziksel fonksiyon & $75(0-100)$ & $65(20-100)$ & 0.057 \\
\hline Ağıı & $77.5(10-100)$ & $67.5(20-100)$ & 0.255 \\
\hline Genel sağlık durumu & $60(15-100)$ & $50(5-95)$ & $0.016^{*}$ \\
\hline Fiziksel rol kısıt|l|lığı & $75(0-100)$ & $50(0-100)$ & $0.001^{*}$ \\
\hline Emosyonel rol kısıtlı|ı̆ı & $100(0-100)$ & $100(0-100)$ & 0.058 \\
\hline Sosyal fonksiyon & $62.5(0-100)$ & $50(0-100)$ & $0.020^{*}$ \\
\hline Mental sağlık & $72(12-100)$ & $72(20-92)$ & 0.353 \\
\hline
\end{tabular}

Araştırma grubunun çalışma şekline göre yaşam kalitesi indeksi alt parametreleri değerlendirildiğinde, fiziksel fonksiyon, ağrı, genel sağlık durumu, fiziksel rol kısıtlıı̆̆ emosyonel rol kısıtlılığı, sosyal fonksiyon, mental sağlık arasında anlamlı farklılık yoktur. ( $p>0.05$ ) Canlılık değeri ortalaması sürekli gündüz çalışanlarda $55.35 \pm 21.04$; sürekli gece çalışanlarda $58.41 \pm 21.28$; vardiya sistemiyle çalışanlarda $54.70 \pm 21.26$ olup sürekli gece çalışanların canlıık ortalaması vardiya çalışanlarından 
anlamlı olarak yüksektir. $(p<0.05)$ (Tablo 4)

\begin{tabular}{|c|c|c|c|c|}
\hline \multirow{3}{*}{$\begin{array}{l}\text { Yaşam Kalitesi } \\
\text { İndeksi } \\
\text { Alt Parametreleri }\end{array}$} & \multicolumn{3}{|c|}{ Çalışma şekli } & \multirow{3}{*}{$p$} \\
\hline & Gündüz & Gece & Vardiya & \\
\hline & Ort.(Min-Max) & Ort.(Min-Max ) & Ort.(Min-Max) & \\
\hline Vitalite(AO $\pm S S)$ & $55.35 \pm 21.04$ & $58.41 \pm 21.28 \mathrm{a}$ & $54.70 \pm 21.26 b$ & 0.02 \\
\hline Fiziksel fonksiyon & $75(0-100)$ & $65(10-100)$ & $70(25-100)$ & 0.78 \\
\hline Ağrı & $67.5(10-100)$ & $77.5(32.5-100)$ & $67.5(22.5-100)$ & 0.77 \\
\hline Genel sağlık durumu & $55(5-100)$ & $60(15-95)$ & $50(15-95)$ & 0.68 \\
\hline Fiziksel rol kısıtılığı & $75(0-100)$ & $100(0-100)$ & $50(0-100)$ & 0.45 \\
\hline $\begin{array}{l}\text { Emosyonel rol } \\
\text { kısıtlılığı }\end{array}$ & $100(0-100)$ & $100(0-100)$ & $66.7(0-100)$ & 0.46 \\
\hline Sosyal fonksiyon & $62.5(0-100)$ & $62.5(100)$ & $50(12.5-100)$ & 0.16 \\
\hline Mental sağlık & $72(12-100)$ & $72(20-100)$ & $68(16-92)$ & 0.25 \\
\hline
\end{tabular}

a b'den farklıdır.

Çalışma grubunun çalışlan bölüme göre yaşam kalitesi indeksi alt parametreleri değerlendirildiğinde, canlılık, fiziksel fonksiyon, ağrı, sosyal fonksiyon, mental sağlık arasında anlamlı farklıık yoktur. $(p>0,05)$ Genel sağılık durumu ortancası serviste çalş̧anlarda 60 , yoğun bakımda çalışanlarda 50 ameliyathanede çalışanlarda 70 , acil servis çalışanlarında 55 diğer bölümlerde çalışanlarda 55 olup, yoğun bakımda çalışanların genel sağlık durumu ameliyathanede çalışanların genel sağlık durumundan anlamlı olarak farkıdır $(p<0.05)$. Fiziksel rol kısıtllı̆̆ı serviste çalışanlarda 75 , yoğun bakımda çalışanlarda 62.5 , ameliyathanede çalışanlarda 100 , acil servis çalışanlarında 50 , diğer bölümlerde çalışanlarda 50 olup, ameliyathanede çalışanların fiziksel rol kısıtlılığı diğer bölümde çalışanların fiziksel rol kısıtllı̆̆ından anlamlı olarak farklıdır $(p<0.05)$ Emosyonel rol kısıtllığı, serviste çalışanlarda 100, yoğun bakımda çalışanlarda 100, ameliyathanede çalışanlarda 100, acil servis çalışanlarında 66.7 diğer bölümlerde çalışanlarda 66.7 olup, ameliyathanede çalışanların emosyonel rol kısıtllı̆̆ı yoğun bakımda ve diğer bölümlerde çalışanlardan farkııır( $p<0.05)($ Tablo 5$)$

\begin{tabular}{|c|c|c|c|c|c|c|}
\hline \multicolumn{7}{|l|}{ Çalışılan bölüm } \\
\hline & Servis & Yoğun bakım & Ameliyathane & Acil & Diğer & \\
\hline & Ort.(Min-Max) & Ort.(Min-Max) & Ort.(Min-Max) & Ort.(Min-Max) & Ort.(Min-Max) & \\
\hline Vitalite(AO $\pm \mathrm{SS})$ & $53.73 \pm 22.05$ & $53.21 \pm 19.96$ & $63.69 \pm 23.84$ & $53.82 \pm 17.63$ & $55.74 \pm 21.26$ & 0.307 \\
\hline Fiziksel fonksiyon & $70(0-100)$ & $75(30-100)$ & $80(35-100)$ & $50(25-100)$ & $70(0-100)$ & 0.084 \\
\hline Ağrı & $70(20-100)$ & $\begin{array}{l}\text { 67.5(22.5- } \\
100)\end{array}$ & $77.5(20-100)$ & $\begin{array}{c}\text { 67.5(32.5- } \\
100)\end{array}$ & $67.5(10-100)$ & 0.240 \\
\hline $\begin{array}{l}\text { Genel sağlık } \\
\text { durumu }\end{array}$ & $60(5-100)$ & $50(15-95) a$ & $70(25-100) b$ & $55(30-85)$ & $55(25-95)$ & 0.026 \\
\hline $\begin{array}{l}\text { Fiziksel rol } \\
\text { kısıtlılığ }\end{array}$ & $75(0-100)$ & $62.5(0-100)$ & $\begin{array}{c}100(25- \\
100) a\end{array}$ & $50(25-100)$ & $50(0-100) b$ & 0.023 \\
\hline $\begin{array}{l}\text { Emosyonel rol } \\
\text { kısıtllığıl }\end{array}$ & $100(0-100)$ & $100(0-100) \mathrm{a}$ & $\begin{array}{l}100(66.7- \\
100) b\end{array}$ & $66.7(0-100)$ & $66.7(0-100) \mathrm{c}$ & 0.032 \\
\hline Sosyal fonksiyon & $75(0-100)$ & $50(12.5-100)$ & $62.5(0-100)$ & $\begin{array}{c}50(12.5- \\
87.5)\end{array}$ & $62.5(25-100)$ & 0.139 \\
\hline Mental sağlık & $72(20-100)$ & $68(12-100)$ & $80(48-96)$ & $72(36-92)$ & $72(12-92)$ & 0.223 \\
\hline
\end{tabular}

a b'den farklıdır.
Sakarya Tıp Dergisi

2018;8(2):292-302

FIRINCI ve Ark.

Hasta Bakıclarda Bel Ağrısı Ve Yașam Kalitesinin

Değerlendirilmesi, Turgut Özal Tip Merkezi Örneği 
Sakarya TIp Dergisi 2018;8(2):292-302
Yaş grupları, VKi, sigara içme, spor yapma, medeni durum, çocuk sayısı, çalışma yılına, eğitim durumu, aylık gelir, ailede başka çalışan varlığı değişkenleri ile yaşam kalitesi indeksi alt parametreleri değerlendirildiğinde- canlılık, fiziksel fonksiyon, ağıı, genel sağlık durumu, fiziksel rol kıııtlı̆ı̆ı emosyonel rol kısıtlılığ, sosyal fonksiyon, mental sağlık- anlamlı farkılık bulunamamıştır(p>0.05)

\section{Tartışma}

Bel ağıısının özellikle sağlık çalışanlarında en fazla karşılaşılan kas-iskelet sistemi hastalığı olduğu bildirilmektedir. ${ }^{11,12}$ Doktor, hemşire, sağlık memuru, fizyoterapist, hasta bakıcı gibi çeşitli sağlkk çalışanları ile yapılan çalışmalarda bel ağrısının önemli bir problem olduğu görülmektedir.

Çalışmamızda ODI değerlendirildiğinde genel grubun ort.(min.-max.) değerleri 12(0-66) olup, hasta bakıcılarda bel ağrısının günlük hayatlarını hafif düzeyde etkilediği görülmüştür. Katılanların $\% 72$ 'sinin hafif(0-20) düzeyde, \%22,4'ünün orta (20-40) düzeyde, \%5,2'sinin günlük hayatının ciddi düzeyde etkilendiği saptanmıştır. 2007-2008 yıllarında bir devlet hastanesinde çalışan sağIık çalışanlarının bel ağrısının değerlendirildiği bir çalışmada Oswestry bel ağrısı ölçeğine göre $\% 45$ 'inde hafif, \%11.7'sinde orta, \%3.3'ünün ciddi derecede bel ağıısı şikayetleri olduğu belirlenmiştir.5 Çalışmamızla uyumlu olarak 206 sağlık personelinin değerlendirildiği bir çalışmada hasta bakıcılarda kas iskelet sistemi ağrılarının diğer meslek gruplarına göre daha düşük oranda tespit edilmiştir. Oysa Eriksen'in 6845 hasta bakıcıda yaptığı çalışmada bel ağrısının \%88 oranında görüldüğü, \%51'inin şiddetli ağrısının olduğu saptanmıştı. ${ }^{13}$ Çalışma grubumuzda bel ağrııının hafif düzeyde olması, ağıının önemsenmeyişi ya da semptomların doğal sayıımasıyla ilgili olabilir.

Bir üniversite hastanesinde gerçekleştirilmiş bu çalışmada kadınların bel ağrısı engelliliği erkeklerden anlamlı olarak yüksek bulunmuştur. Bir devlet hastanesinde çalışan 167 sağlık çalsşanını kapsayan bir çalışmada kadınların bel ağrısı puanlarının erkeklerden yüksek olduğu belirlenmiştir.5 Benzer şekilde Hong Kong'da 2006 yılında yapılan bir çalışmada kadınlarda bel ağrısı daha sık görülmektedir. ${ }^{14}$ Gazi Üniversitesi hastanesinde yapılmış olan bir çalışmada cinsiyetler arasında bel ağıısı görülme sıklığı açısından fark saptanmamıştır. ${ }^{6}$ Ülkemiz şartlarında kadınların iş yükünün evde de devam ediyor olması, kadınların fiziksel dayanıklılığın daha az olması, kadınlarda neden bel ağrııının günlük hayatı erkeklerden daha fazla kısıtladığını açıklamaktadır.

Çalışma grubunun yaş grupları ile bel ağıısı puan ortalaması karşılaştıııldığında, bel ağrııı puan ortancası 31 - 35 yaşta en fazla 16(0-66) olarak belirlenmiştir. Yapılan analiz sonucunda yaş ile bel ağıısı puan ortalaması arasında istatistiksel olarak anlamlı bir fark bulunmamıştır $(p>0.05)$. Kabataş ve ark. yaptığı çalışmada bel ağrısı puan ortalamasının en fazla 34-39 yaş aralığında olmasına karşın yaş grupları arasında anlamlı fark bulunamamıştır.5 Aksakal ve arkadaşlarının yaptığı çalışmada yaş grupları arasında anlamlı fark bulunmamakla birlikte yakınma en sık 40-49 yaş grubundaki kişilerde bidirilmiştir.6 Kayseri'de 3800 yetişkin ile yapılmış çalışmada artan yaşın bel ağrısı açısından risk faktörü olduğu saptanmıştır. ${ }^{15}$ Çalışmamıza katılan hasta bakıııların yaş ortalaması 37.3 çalışma yılı ortalamasının 9.97'dir. Yaşın ilerlemesiyle hasta bakıcıların tecrübe sahibi olması ve riskli davranışlardan kaçınma eğilimi, genç ve tecrübesiz personelde kas- iskelet sistemi hastalıklarının ortaya çıkması için gerekli maruziyet süresinin geçirilmemiş olması, genç bireylerin spor yapma konusunda daha bilinçli davranış sergilemesi kas- iskelet sistemi hastalıklaının günlük yaşamı etkilemesi durumuna yaşın tek başına yeter sebep olamayacağını düşündürmektedir. 
Çalışmamızda hasta bakıcıların \%52.8'inin sigara içtiği bulunmuştur. Sağlık çalışanlarında sigara içme prevelansı \%38.3 - 68,9 arasında bulunmuş̧ur. ${ }^{5,6,16}$ Değiştirilebilen bir risk faktörü olan sigara kullanma alışkanlığının bel ağrıı üzerindeki etkisini inceleyen çeşitli çalışmalar bulunmaktadır. ${ }^{17,18}$ Çalışmamızda sigara içme ile bel ağrısı puan ortalaması arasında yapılan analiz sonucunda istatistiksel olarak anlamlı bir fark bulunmamıştır. Selçuk üniversitesinde sigara kullanımı ile bel ağrısı ilişkisini inceleyen bir çalışmada çalışmamıza benzer şekilde sigara kullanımının bel ağrısı üzerine etkisinin olmadığı saptanmıştr. ${ }^{17}$ Başkent üniversitesinde 2016 yılında yapılan bir çalışmada günlük sigara kullanımı ile Oswestry Bel Ağrısı Anketi değerleri arasında pozitif ilişki saptandı. ${ }^{19}$ Bel ağrıIInın sigara kullanım süresi ve miktarı ile ilişkili olabileceği göz önünde tutulursa sigara kullanımının kas iskelet sistemi ağıılarılla ilişkisini ve kişilerin günlük yaşamı üzerindeki etkilerini inceleyen daha fazla çalışmaya ihtiyaç duyulmaktadır.

Çalışma şekline göre ODI açısından gruplar arasında anlamlı fark bulunamamıştır. Literatürde vardiya usulü çalışmanın uyku, beslenme ve egzersiz alışkanlıklarını değiştirdiği ve kişileri olumsuz olarak etkilediğinden söz edilmektedir. ${ }^{6,20}$

Çalışmamızda spor yapma açısında değerlendirildiğinde ODI açısından gruplar arasında anlamlı fark tespit edilmemiş olmasına rağmen düzenli egzersiz yapan veya aktif sporcu olduğunu belirten grupta ODI değerleri egzersiz yapmayan gruptan daha düşük bulunmuştur. Bel ağrısı çeken orta yaş sedanter bayanlarda dört haftalık bel egzersizlerinin ağrı durumuna etkisini tespit etmek amacı ile yapılan çalışmada katılımcıların ağ̊ı, kişisel bakım, ağılık kaldırma, yürüme, oturma, uyku, gezi, cinsel ve sosyal yasam değerlerinde egzersiz programı sonrasında ağrılarının azaldığı tespit edilmiştir. ${ }^{21}$ iş ortamındaki olumsuz koşullar sonucunda; stres ve anksiyete gibi psikolojik durumlar, kas iskelet sistemi bozukları çeşitli hastalıklar ortaya çıkmaktadır. ${ }^{22}$ Bel ağrısı olan hastaların hem ağrı hem de fiziksel kısıtllııklar nedeniyle yaşam kaliteleri etkilenmektedir. ${ }^{23}$

Genel sağlık durumunun ortancası erkeklerde 60, kadınlarda 50; Fiziksel rol kısıtlılığının ortancası erkeklerde 75, kadınlarda 50; Sosyal fonksiyon erkeklerde 62.5, kadınlarda 50 olup, kadın çalışanlarda yaşam kalitesi alt parametreleri anlamlı olarak daha düşük bulunmuştur. Çalışmamıza benzer şekilde bel ve boyun ağrılı hastalarda anksiyete, depresyon ve yaşam kalitesinin araştııldığı bir çalışmada Kadınların ve bel ağrısı olanların yaşam kalitesi skorları erkeklerden ve boyun ağrısı olanlardan anlamlı derecede daha düşük bulunmuştur. ${ }^{23}$

Araştırma grubunun çalışma şekline göre yaşam kalitesi indeksi alt parametreleri değerlendirildiğinde, fiziksel fonksiyon, ağrı, genel sağlık durumu, fiziksel rol kısıtllığı, emosyonel rol kısıtllığı, sosyal fonksiyon, mental sağlık arasında anlamlı farklılık yoktur. Canlılık değeri ortalaması sürekli gündüz çalışanlarda 55.35 \pm 21.04 ; sürekli gece çalışanlarda $58.41 \pm 21.28$; vardiya sistemiyle çalışanlarda $54.70 \pm 21.26$ olup sürekli gece çalışanların canlılık ortalaması vardiya çalışanlarından anlamlı olarak yüksektir. Sağlık çalışanlarında vardiyalı çalışma sisteminin sebep olduğu genel ruhsal belirtiler ve yaşam kalitesi üzerine etkisinin araştııılığı bir çalışmada vardiyalı çalışan grupta, SF-36 alt ölçeklerinden fiziksel fonksiyon ve ağrı alanlarında yaşam kalitesinin gündüz çalş̧anlara göre daha bozuk olduğu, genel sağlık, fiziksel rol güçlüğü, emosyonel rol güçcügü, mental sağılı, enerji ve sosyal fonksiyon yönünden iki grup arasında anlamlı farklılık bulunmadığı tespit edilmiştir. ${ }^{24}$ Vardiyalı veya gece çalışmanın yaşam kalitesine etkisini değerlendirmek için daha büyük örneklem grubunda, daha fazla sayıda çalışmaya ihtiyaç duyulmaktadır.
Sakarya Tıp Dergisi

2018;8(2):292-302

FIRINCI ve Ark.

Hasta Bakıclardar Bel Ağ̊ııı Ve Yaşam Kalitesinin

Değerlendirllmesi, Turgut Özal Tip Merkezi Örneği 
Sakarya TIp Dergisi 2018;8(2):292-302

FIRINCI ve Ark. Hasta Bakıcılarda Bel Ağıısı Ve Yașam Kalitesinin Değerlendirilmesi, Turgut Özal Tip Merkezi Örneği
Çalışma grubumuzda egzersiz yapma durumuna göre yaşam kalitesi indeksi alt parametreleri arasında anlamlı farkılık bulunamamıştır. Kronik bel ağrılı hastalarda fizyoterapi programının fonksiyonel kapasite ve yaşam kalitesi üzerine etkisinin araştıııldığı bir çalışmada SF-36 Yaşam Kalitesi Ölçeği tedavi öncesi ve sonrası değerlendirmeleri karşılaştıııldığında ise; Fiziksel fonksiyon, fiziksel rol güçlüğü, ağrı, genel sağlı, canlılı, sosyal fonksiyon, emosyonel rol güçlüğü, mental sağlk değerlendirmelerinde istatistiksel olarak anlamlı düzelmeler saptanmıştır. ${ }^{25}$ Yapılan bir çalışmada fiziksel aktivitenin, tüm gruplarda sağlıkla ilişkili yaşam kalitesinin fiziksel fonksiyonu ve canlılık alt parametreleri ile ilişkili olduğu bulunmuştur. ${ }^{26}$ Çalışmamızda egzersiz yapan grupta yaşam kalitesinin yükseldiği fakat bu yükselişin anlamlı olmadığı görülmektedir. Bu durumun egzersiz türü ve süresiyle ilişkili olabileceği düşünülmektedir.

\section{Sonuç}

Çalışmamızda hasta bakıcılarda yaşanan bel ağrııı sorununun günlük hayatlarını hafif düzeyde etkilediği sonucuna ulaşılmıştır. Bel ağıısı çalışanların yaşam kalitesini ve iş verimliliğini olumsuz etkileyen bir hastalıktır. Hem bireysel faktörler hem de iş yeri ortam faktörleri bu durumun ortaya çıkmasında etkilidir. Sık sık kaldırma, indirme, itme, çekme gibi işleri yapan hasta bakıcıların bu tekrarlayan hareketleri ergonomik kurallara uygun olarak yapması, iş yerinin ergonomik olarak düzenlenmesi bel ağrısının ortaya çıkma ihtimalini azaltacak, iş verimliliğini yükselecektir.

Hizmet içi eğitimlerde vücut mekaniklerine dikkat etmenin ve egzersizin öneminin vurgulanarak bel sağlığını koruyucu egzersiz eğitimlerinin planlanması önerilebilir. Eğitim yoluyla çalışanların konu ile ilgili farkındalığın artırılması sağlanabilir. Doğru şekilde yapılan egzersizler ile kişilerin kas gücü ve dayanıklılığının artması ve yaşam kalitelerinin yükselmesi sağlanabilir. Çalışma şekli ve sürelerinin düzenlenmesi ve yardımcı araç-gereç kullanımının özendirilmesi bel ağrısı sorununun çözümüne yardımcı olacaktır. Bu yaklaşımlarla sağlık personelinin yaşam kalitesi arttırılabileceği gibi, ağıının yol açıı̆̆ iş gücü kaybı da en aza indirilebilir. 
1. KARABABA A O. Bel ağıısı epidemiyolojisi. Turkiye Klinikleri Journal of NeuroSurgery Special Topics 2010; 3(1), 1-7.

2. Freimann T, Coggon D, Merisalu E, Animägi L, \& Pääsuke M. Risk factors for musculoskeletal pain amongst nurses in Estonia: a cross-sectional study. BMC musculoskeletal disorders 2013; 14(1), 334.

3. Hasanefendioğlu E. Z, Sezgin M, Sungur M A, Cimen Ö B, İncel N A \& Sahin G. Kronik Bel Ağrılı Hastalarda Sağlıkla ilișkili Yașam Kalitesi: Ağıı, Klinik ve Fonksiyonel Durumun Yaşam Kalitesi Üzerine Etkisi. Journal of Physical Medicine \& Rehabilitation Sciences/Fiziksel Tip ve Rehabilitasyon Bilimleri Dergisi 2012; 15(2).

4. Dündar Ü, Solak Ö, Demirdal Ü S, Toktaş H \& Kavuncu V. Kronik bel ağrıl hastalarda ağıı, yeti yitimi ve depresyonun yaşam kalitesi ile ilişkisi. Gene Tip Dergisi 2009; 19(3)

5. Kabataş M S, Kocuk M \& Küçükler Ö. Sağlık Çalışanlarında Bel Ağrısı Görülme Sıkı̆̆ı ve Etkileyen Faktörlerin İncelenmesi. Fırat Üniversitesi Sağlık Bilimleri Tıp Dergisi 2012; 26(2), 65-72.

6. Aksakal N, ilhan M N, Yüksel H, Kurtcebe Ö \& Bumin M A. Bir Üniversite Hastanesinde Hemşire, Sağlık Memuru Ve Hastabakıcilarda Bel Ağrıs Sıklı̆ı Ve Etkileyen Faktörler. Mesleki Sağlık Ve Güvenlik Dergisi (MSG 2015; 9(32).

7. Armand, Stéphane, et al. Effects of unstable shoes on chronic low back pain in health professionals: A randomized controlled trial. Joint Bone Spine 81.6 2014; 527-532

8. Patrick, Nathan, Eric Emanski, and Mark A. Knaub. Acute and chronic low back pain. Medical Clinics of North America 98.4 2014; 777-789.

9. Yakut E, Düger T, Öksüz Ç, Yörükan S, Üreten K, Turan D, et all. Validation of the Turkish version of the Oswestry Disability Index for patients with low back pain. Spine 2004; 29(5), 581-585.

10. Koçyiğit H, Aydemir Ö, Fişek G, Ölmez N \& Memiş A K. Form-36 (SF36)'nın Türkçe versiyonunun güvenilirliği ve geçerliliği. Ilaç ve tedavi dergisi 1999; 12(1), 102-6.

11. Davis K G \& Kotowski S E. Prevalence of musculoskeletal disorders for nurses in hospitals, long-term care facilities, and home health care: a comprehensive review. Human factors, 2015; 57(5), 754-792.

12. Mehrdad R, Shams-Hosseini N S, Aghdaei S \& Yousefian M. Prevalence of low back pain in health care workers and comparison with other occupational categories in Iran: A systematic review. Iranian journal of medical sciences 2016: 41(6), 467.

13. DIRAÇOĞLU D. Sağlık Personelinde Kas-iskelet Sistemi Ağrıları. Turkiye Klinikleri Journal of Medical Sciences 2006; 26(2), 132-139.

14. Cheung K, Gillen M, Faucett J \& Krause N. The prevalence of and risk factors for back pain among home care nursing personnel in Hong Kong. American journal of industrial medicine 2006; 49(1), 14-22
15. YILMAZ Y,\& KAYA M. Risk factors for low back pain and its relation with pain related disability and depression in a Turkish sample. Turkish Neurosurgery 2009; 19(4), 327-332.

16. Urgan N \& Hamzaoğlu O. KOCAELi ÜNIVERSiTESI TIP FAKÜLTESI'NDE ÇALIŞAN ASISTANLAR ARASINDA BEL AĞRISI SIKLIĞI VE BEL AĞRISINI ETKILEYEN FAKTÖRLERIN iNCELENMESi. Mesleki Sağlık ve Güvenlik Dergisi (MSG) 2017; 16(60-61)

17. Albayrak i, Şahin N, Karahan A Y \& Uğurlu H. Sigara kullanımının bel ağrıs ile ilişkisi. Genel Tip Dergisi 2010; 20(2), 55-59.

18. Orhurhu V J, Pittelkow T P \& Hooten W M. Prevalence of smoking in adults with chronic pain. Tobacco induced diseases 2015; 13(1), 17

19. Aytar A, Yürük Z Ö, Durutürk N, Kunduracılar Z \& Tığlı A. Bel Ağrılı Has talarda Günlük Sigara Kullanımı Ile Ağrı ve Fonksiyonel Yetersizlik Arasındaki İlișki. Bașkent Üniversitesi Sağılk Bilimleri Fakültesi Dergisi-BÜSBiD 2016; 1(2)

20. Trinkoff A M, Le R, Geiger Brown J, Lipscomb J \& Lang G. Longitudina relationship of work hours, mandatory overtime, and on call to musculoskeletal problems in nurses. American journal of industrial medicine 2006; 49(11), 964-971.

21. Arıkan B, Hazar S \& Arıkan E. The effect of low back exercise on the pain condition of sedentary women who Suffering from low back pain. Journal of Human Sciences 2010; 7(2), 671-681.

22. Yılmaz E \& Özkan S. Bir Illçede Çalışan Hemşirelerin Sağlık Sorunları ve Yaşam Alışkanlıklarının Değerlendirilmesi. Fırat Sağık Hizmetleri Dergisi 2006; 1(3), 81-99.

23. Yazici K, Tot Ş, BiçER A, Yazici A \& Buturak V. Bel ve boyun ağrııı olan hastalarında anksiyete, depresyon ve yașam kalitesi. Klinink Psikiyatri 2003; 6, 95-101.

24. Selvi Y, Özdemir P G, Özdemir O, Aydın A \& Beşiroğlu L. Sağlık çalışanlarında vardiyalı çalıșma sisteminin sebep olduğu genel ruhsal belirtiler ve yașam kalitesi üzerine etkisi. Düșünen Adam Psikiyatri ve Nörolojik Bilimler Dergisi 2010; 23(4), 238-43.

25. Narin S, Bozan Ö, Cankurtaran F \& Bakırhan S. Kronik bel ağrılı hastalarda fizyoterapi programının fonksiyonel kapasite ve yaşam kalitesi üzerine etkisi. Dokuz Eylül Üniversitesi Tip Fakültesi Dergisi 2008 ; 22(3), 137-143.

26. Soysal M, Kara B, Arda M N. Assessment Of Physical Activity in Patients With Chronic Low Back Or Neck Pain. Turkish Neurosurgery 2013 23(1), 75-80.
Sakarya Tıp Dergisi

2018;8(2):292-302

FIRINCI ve Ark.

Hasta Bakıcılarda Bel Ağrııı Ve Yaşam Kalitesinin

Değerlendirilmesi, Turgut Özal Tıp Merkezi Örneği 